\title{
Article
}

\section{Exercise Ameliorates Spinal Cord Injury by Changing DNA Methylation}

\author{
Ganchimeg Davaa ${ }^{1,2} \oplus^{1}$, Jin Young Hong ${ }^{1,2}$, Tae Uk Kim ${ }^{3}{ }^{\oplus}$, Seong Jae Lee ${ }^{3}{ }^{\circ}$, Seo Young Kim ${ }^{3}$, Kwonho Hong ${ }^{4}$ \\ and Jung Keun Hyun $1,2,3,5, *$ (1)
}

1 Department of Nanobiomedical Science \& BK21 FOUR NBM Global Research Center for Regenerative Medicine, Dankook University, Cheonan 31116, Korea; ganchimeg12@gmail.com (G.D.); vrt23@naver.com (J.Y.H.)

2 Institute of Tissue Regeneration Engineering (ITREN), Dankook University, Cheonan 31116, Korea

3 Department of Rehabilitation Medicine, College of Medicine, Dankook University, Cheonan 31116, Korea; magnarbor@dankook.ac.kr (T.U.K.); rmlee@dankook.ac.kr (S.J.L.); juliet8383@naver.com (S.Y.K.)

4 Department of Stem Cell and Regenerative Biotechnology and Institute of Advanced Regenerative Science, Konkuk University, Seoul 05029, Korea; hongk@konkuk.ac.kr

5 Wiregene, Co., Ltd., Cheonan 31116, Korea

* Correspondence: rhhyun@dankook.ac.kr; Tel.: +81-10-2293-3415

check for updates

Citation: Davaa, G.; Hong, J.Y.; Kim, T.U.; Lee, S.J.; Kim, S.Y.; Hong, K.; Hyun, J.K. Exercise Ameliorates Spinal Cord Injury by Changing DNA Methylation. Cells 2021, 10, 143. https://doi.org/10.3390/cells10010143

Received: 29 November 2020

Accepted: 11 January 2021

Published: 12 January 2021

Publisher's Note: MDPI stays neutral with regard to jurisdictional clai$\mathrm{ms}$ in published maps and institutional affiliations.

Copyright: $\odot 2021$ by the authors. Licensee MDPI, Basel, Switzerland. This article is an open access article distributed under the terms and conditions of the Creative Commons Attribution (CC BY) license (https:// creativecommons.org/licenses/by/ $4.0 /)$.

\begin{abstract}
Exercise training is a traditional method to maximize remaining function in patients with spinal cord injury (SCI), but the exact mechanism by which exercise promotes recovery after SCI has not been identified; whether exercise truly has a beneficial effect on SCI also remains unclear. Previously, we showed that epigenetic changes in the brain motor cortex occur after SCI and that a treatment leading to epigenetic modulation effectively promotes functional recovery after SCI. We aimed to determine how exercise induces functional improvement in rats subjected to SCI and whether epigenetic changes are engaged in the effects of exercise. A spinal cord contusion model was established in rats, which were then subjected to treadmill exercise for 12 weeks. We found that the size of the lesion cavity and the number of macrophages were decreased more in the exercise group than in the control group after 12 weeks of injury. Immunofluorescence and DNA dot blot analysis revealed that levels of 5-methylcytosine $(5 \mathrm{mC})$ and 5-hydroxymethylcytosine (5hmC) in the brain motor cortex were increased after exercise. Accordingly, the expression of ten-eleven translocation (Tet) family members (Tet1, Tet2, and Tet3) in the brain motor cortex also elevated. However, no macrophage polarization was induced by exercise. Locomotor function, including Basso, Beattie, and Bresnahan (BBB) and ladder scores, also improved in the exercise group compared to the control group. We concluded that treadmill exercise facilitates functional recovery in rats with $\mathrm{SCI}$, and mechanistically epigenetic changes in the brain motor cortex may contribute to exerciseinduced improvements.
\end{abstract}

Keywords: spinal cord injury; exercise; epigenetics; DNA methylation; 5-hydroxymethylcytosine; ten-eleven translocation

\section{Introduction}

Spinal cord injury (SCI) is a major devastating lesion, and neurological recovery after SCI is rarely seen in the clinical setting. Exercise training was recommended for SCI patients in the rehabilitation unit several decades ago. The main reason for locomotor training in SCI patients was initially to maximize the remaining muscle function to replace the impaired function caused by disconnected motor tracts in the spinal cord. However, some researchers have reported functional recovery after exercise training in animal SCI models, and they explained this phenomenon in three ways: compensation, regeneration, and neuronal plasticity. The compensation mechanism was explained by the proper balance among the central pattern generator below the lesion, sensory feedback, and the remaining descending pathways from the cerebrum and brainstem after SCI $[1,2]$. 
Regeneration of corticospinal tracts was enhanced by extracellular signal-regulated protein kinase 1/2 (ERK1/2) activation in SCI rats [3]. Numerous previous studies reported an increase in neuronal plasticity after locomotor training, with upregulation of various neurotrophic factors, including brain-derived neurotrophic factor (BDNF) and glial cell line-derived neurotrophic factor (GDNF) in the spinal cord [4,5] and BDNF, microtubuleassociated protein 2 (MAP-2), and synaptophysin in the motor cortex [6], or modulation of the phosphatase and tensin homolog (PTEN)/mammalian target of rapamycin (mTOR) signaling pathway [7] in animal SCI models.

DNA methylation at the 5-position of cytosine $(5 \mathrm{mC})$ and demethylation through the conversion of $5 \mathrm{mC}$ to $5 \mathrm{hmC}$ is important to regulate axonal regeneration in the central and peripheral nervous systems [8]. Several epigenetic modifications have been reported promoting functional recovery following SCI $[9,10]$. Therefore, DNA methylation and demethylation may contribute to enhance regenerative capacity in SCI.

In our recent study, we showed that level of DNA demethylation is changed after SCI, and the administration of ascorbic acid could effectively promote DNA hypermethylation and enhance functional restoration in rat SCI models [11]. Previous studies have shown that metabolic and signaling changes during exercise may affect the epigenetic status of skeletal muscles [12-14] and the brain [15,16]; however, changes in epigenetic status caused by locomotor training have not yet been elucidated. Recently, hippocampal ten-eleven translocation 1 (Tet1) and Tet2 expression were found to increase after active exercise, which may be related to memory restoration in aged mice [17]. Our previous finding that Tet 1 and Tet2 expression increased in the brain motor cortex was partially related to improvement in locomotor functions [11]; therefore, exercise-induced epigenetic changes may be expected to promote neuronal recovery after SCI.

The effects of exercise training on SCI have also been debated. Exercise following SCI is known to promote functional restoration and reduce neuropathic pain [18]. However, some researchers have reported that combination therapies using stem cell transplantation $[19,20]$ and chemical agents [21,22] were effective for only functional improvements, and exercise even worsened allodynia via aberrant sprouting of $C$ fibers through BDNF-tropomyosin receptor kinase B (TrkB) signaling [23] and exacerbated the inflammatory response after SCI [24].

In this study, we aimed to investigate whether treadmill exercise promotes histological and functional recovery in rats subjected to SCI and whether epigenetic changes are related to these results.

\section{Materials and Methods}

\subsection{Animals and Surgical Procedures}

Adult female Sprague-Dawley rats (12 weeks old, 230-250 g) were used in this study. All experimental procedures were approved by Dankook University's Institutional Animal Care and Use Committee (approval No. 19-009). Animals were individually housed in clear plastic cages under a $12 \mathrm{~h}$ light/dark cycle with free access to food and water at room temperature $\left(24 \pm 1{ }^{\circ} \mathrm{C}\right)$ and a humidity of $45-50 \%$. Rats were randomly divided into a control group without exercise $(n=13)$ and the experimental group, which received treadmill exercise $(n=14)$ (Figure 1). The surgical procedures for SCI have been previously described in detail [25]. Briefly, animals were deeply anesthetized with isoflurane (Forane; Choongwae Pharma, Seoul, Korea), and T9 laminectomy was performed to expose the thoracic spinal cord. Moderate contusion injury ( $200 \mathrm{kdyn})$ was induced using the Infinite Horizon impactor (Precision Systems and Instrumentation, LLC, Fairfax, VA, USA). After SCI, the muscles and skin were sutured with sterile 5-0 sutures. Intramuscular injection of cefotiam hydrochloride $\left(40 \mathrm{mg} / \mathrm{kg}\right.$; Fontiam ${ }^{\mathrm{TM}}$, Hanmi Pharma, Seoul, Korea) was performed in all operated rats for 3 days, and intraperitoneal injection of normal saline $(0.9 \% ; 3 \mathrm{~mL})$ was performed just after surgery. Each rat also received oral administration of acetaminophen syrup (10 mg/kg; Tylenol ${ }^{\mathrm{TM}}$, Janssen Pharmaceutica, Titusville, NJ, USA) 
for 3 days, and manual bladder expression was performed twice daily until spontaneous bladder expression was reestablished.

\begin{tabular}{|c|c|c|c|c|}
\hline & $\begin{array}{l}\text { Treadmill exercise } \\
\qquad(30 \mathrm{~min} / \mathrm{d})\end{array}$ & \multicolumn{2}{|c|}{ Treadmill exercise $(30 \mathrm{~min} / \mathrm{d}, 5 \mathrm{~d} / \mathrm{w}$ ) } & \multirow[b]{2}{*}{12} \\
\hline & 0 & 1 & & \\
\hline Timeline (w) & $\begin{array}{c}\text { Surgery } \\
\text { T9 contusion }\end{array}$ & $\begin{array}{l}\text { Grouping } \\
\text { 1. Control, } n=13 \\
\text { 2. Exercise, } n=14\end{array}$ & $\begin{array}{l}\text { Locomotor analysis } \\
\text { (BBB and ladder, weekly) }\end{array}$ & $\begin{array}{l}\text { Sacrifice } \\
\text { Histological analysis ( } n=4 / \text { group) } \\
\text { DNA dot blot analysis }(n=4 / \text { group) } \\
\text { PCR analysis }(n=3 / \text { group) } \\
\text { Bladder analysis ( } n=6 \text { / group) }\end{array}$ \\
\hline
\end{tabular}

Figure 1. Timeline of the experiments.

\subsection{Treadmill Exercise}

Treadmill exercise training was performed using the Exer-3/6 open treadmill with shock for rats (Columbus Instruments, Columbus, OH, USA). The instrument supports exercising the rats in individual lanes at the same time. An electrical stimulus system option with shock grids was used for the exercise. The rats were exercised for 1 week before surgery for adaptation. The exercise schedule was started 1 week after injury, and treadmill exercise was performed twice per day (morning and afternoon for $15 \mathrm{~min}$ per session) and 5 days per week for 12 weeks after injury (Figure 1). Treadmill exercise was conducted at a running speed of $5 \mathrm{~m} / \mathrm{min}$ at the beginning, and the speed was gradually increased to $12 \mathrm{~m} / \mathrm{min}$ as the walking capabilities of the rats allowed until the end of the training as previously described [26,27].

\subsection{Histology}

Sections of the spinal cord and brain were analyzed by hematoxylin and eosin (H\&E) and immunohistochemical staining. The rats were perfused with $0.9 \%$ normal saline, followed by $4 \%$ paraformaldehyde (Hushi Inc., Shanghai, China) in 0.1 M PBS (pH 7.4). The brains and spinal cords were dissected from the rats, postfixed overnight in $4 \%$ paraformaldehyde at $4{ }^{\circ} \mathrm{C}$, and cryopreserved with $30 \%$ sucrose for 3 days. The tissue samples were embedded in the M1 compound (Thermo Fisher Scientific Inc., Waltham, MA, USA), the spinal cords were cut into $16 \mu \mathrm{m}$ sagittal sections, and the brain samples were cut into $10 \mu \mathrm{m}$ coronal sections using a cryotome cryostat. H\&E staining was performed on the lesion epicenter to examine the general morphology of the spinal cord at 12 weeks after injury, and three sagittal sections containing a lesion cavity and four cases per group were evaluated for quantitative analysis. The size of the lesion cavity was manually outlined for each section under confocal microscopy and analyzed using Image J software ( $1.37 \mathrm{v}$, National Institutes of Health, Bethesda, MD, USA) as our previous studies [28,29].

\subsection{Immunohistochemistry (IHC)}

Immunohistochemistry was used to analyze DNA methylation within the brain after treadmill exercise and to observe the inflammatory status in the contused spinal cord. Sections were permeabilized with $0.2 \%$ Triton X-100 in $1 \mathrm{X}$ phosphate-buffered solution (PBS) for 5 min, washed with 1 X PBS, and blocked with 10\% normal goat serum in 1X PBS for $1 \mathrm{~h}$. The primary antibodies, mouse anti-5-methylcytosine $(5 \mathrm{mC})$ (1:500, Active Motif, Carlsbad, CA, USA), rabbit anti-5-hydroxymethylcytosine (5hmC) (1:500, Active Motif), mouse anti-NeuN (1:100, Millipore, Bedford, MA, USA), rabbit anti-NeuN (1:1000, Abcam, Cambridge, MA, USA), guinea pig anti-NeuN (1:500, Synaptic Systems, Goettingen, Germany), mouse anti-GFAP (1:1000, MilliporeSigma, St. Louis, MO, USA), rabbit antiGFAP (1:1000, DAKO Cytomation, Carpinteria, CA, USA), mouse anti-monocyte/macrophage ED1 (1:400, Millipore), rabbit anti-5HT (1:2000, MilliporeSigma), rabbit anti-Tet1 (1:100, Abcam), rabbit anti-Tet2 (1:100, Millipore) and rabbit anti-Tet3 (1:100, Santa Cruz, Inc., CA, USA), were incubated overnight at $4{ }^{\circ} \mathrm{C}$. The sections were washed three times and treated with 
secondary antibodies. The secondary antibodies included FITC-, Alexa 594-, and Alexa 647-conjugated antibodies for monoclonal and polyclonal primary antibodies (1:200, Jackson ImmunoResearch, West Grove, PA, USA). After $2 \mathrm{~h}$ of incubation at room temperature, the sections were washed three times with PBS, and the cell nuclei were stained with DAPI (1:1000, MilliporeSigma). The stained tissue sections were imaged using confocal microscopy (Carl Zeiss Inc., Oberkochen, Germany).

Our analysis specifically focused on DNA methylation and demethylation in mature neurons in layers IV-V of the primary motor cortex (M1) within the brain after spinal cord injury. For quantification of the $5 \mathrm{mC}$ and $5 \mathrm{hmC}$ fluorescence intensity, three representative images of the primary motor cortex (M1) of each case and four cases per group were captured at 200X magnification on confocal microscopy. The average intensity of $5 \mathrm{mC}$ or $5 \mathrm{hmC}$ co-staining with NeuN was measured using ImageJ software (National Institutes of Health). For quantitation of ED1-positive monocytes and macrophages in the sagittal section, three images per case and four cases per group were captured at the lesion site using a confocal microscope and then counting the expressed cell numbers within a lesion cavity manually. The mean values of images were expressed as ED1-positive cell numbers per $1 \mathrm{~mm}^{2}$ in each case. Additionally, we examined the intensity of TET family proteins in the captured images. All images were captured using identical microscopy acquisition settings.

For quantification of 5HT axons, three images at the lesion cavity per case and four cases per group were selected. A threshold value was constant for every image, and the density of 5HT-positive axons was expressed. The number of positive pixels was then divided by the total number of pixels using Image J software as previously described $[11,30]$.

We performed NF200 diaminobenzidine (DAB) staining, the sections were washed with PBS, and the peroxidase activity was blocked with $0.3 \% \mathrm{H}_{2} \mathrm{O}_{2}$ in DW for $30 \mathrm{~min}$ at room temperature. After rinsing, the sections were incubated in $0.2 \%$ Triton- $X$ in PBS for $5 \mathrm{~min}, 2 \%$ NGS in PBS for $1 \mathrm{~h}$ at room temperature, and then in the primary rabbit anti-NF200 (1:100 Millipore) antibody in $2 \%$ NGS at $4{ }^{\circ} \mathrm{C}$ overnight. Then, the sections were incubated in biotinylated goat anti-rabbit secondary antibody (1:200 Jackson ImmunoResearch) in $2 \%$ NGS for $2 \mathrm{~h}$ at room temperature, followed by incubation in the Vectastain Elite ABC elite kit (Vector Laboratories, Burlingame, CA, USA) for $30 \mathrm{~min}$. Finally, NF200 staining was revealed with DAB solution (0.05\% 3-3-diaminobenzidine tetrahydrochloride (MilliporeSigma), $0.06 \% \mathrm{NiCl} 2$ (MilliporeSigma), and $0.003 \% \mathrm{H}_{2} \mathrm{O}_{2}$ ), and the reaction was stopped with distilled water. The sections were dehydrated, coverslipped and allowed to dry. The lesion cavity was outlined manually from captured images, and the number of pixels occupied by the NF200-labeled axons from three images per case and four cases per group within the outlined lesion cavity was quantified using ImageJ software (National Institutes of Health). NF200-labeled axonal density was determined by dividing the number of NF200-positive pixels by the number of pixels in a field as described in our previous study [29].

Macrophage subsets in the contused spinal cord were analyzed using immunohistochemistry. The primary antibodies, rabbit anti-GFAP (1:1000, DAKO Cytomation), rabbit antimonocyte/macrophage ED1 (1:400, Abcam), mouse anti-arginase I (1:50, Santa Cruz) and mouse anti-CD86 (1:100, BD Pharmingen, San Diego, CA, USA), were incubated overnight at $4{ }^{\circ} \mathrm{C}$. After the sections were washed three times, goat anti-rabbit (Alexa Fluor 546, Jackson ImmunoResearch) and goat anti-mouse (Alexa Fluor 488, Jackson ImmunoResearch) secondary antibodies were used at a dilution of 1:200 in 2\% NGS in PBS. Following $2 \mathrm{~h}$ of incubation, the sections were washed three times with PBS. The stained tissue sections were imaged using confocal microscopy (Carl Zeiss Inc., Oberkochen, Germany).

Macrophage polarization was quantified by dividing the number of CD86- or arginase I-positive cells by the number of ED1-positive cells with manual cell counting. The images were captured at the lesion site using a confocal microscope to assess the percentages of CD86-positive M1 and Arg1-positive M2 macrophages as previously described [29]. 


\subsection{DNA Dot Blot Assay}

Genomic DNA was extracted from the brain motor cortex in the control and exercise groups using the DNeasy blood and tissue kit (Qiagen, Hilden, Germany) to determine the amount of $5 \mathrm{mC}$ and $5 \mathrm{hmC}$. Purified genomic DNA samples were spotted on a nitrocellulose membrane $(0.2 \mu \mathrm{m}$ pore size) using a 96-well manifold apparatus (Manifold I; Schleicher and Schuell, Dassel, Germany). DNA was immobilized to the membrane by baking at $80^{\circ} \mathrm{C}$ for $2 \mathrm{~h}$. The membrane was then blocked with $5 \%$ skim milk and incubated with mouse anti-dsDNA (1:2000, Abcam), rabbit anti-5mC (1:1000, Active Motif), or rabbit anti-5hmC (1:2000, active motif) at room temperature (RT) for $1 \mathrm{~h}$. The membrane was incubated with a horseradish peroxidase-conjugated antibody specific for mouse or rabbit (Jackson ImmunoResearch) for $1 \mathrm{~h}$ at RT and visualized by enhanced chemiluminescence (Thermo Fisher Scientific Inc.). The relative amounts of $5 \mathrm{hmC}$ and $5 \mathrm{mC}$ in genomic DNA were calculated using ImageQuant TL software (GE Healthcare, Chicago, IL, USA).

\subsection{Real-Time PCR}

To examine the global changes in the expression of the DNA methylation-related genes and inflammation- and regeneration-related genes, the relative mRNA levels of Tet family members (Tet1, Tet2, Tet3), DNA methyltransferase (DNMT) 1, DNMT3a, tumor necrosis alpha (TNF $\alpha$ ), interleukin (IL)-6, IL-1 $\beta$, Krüppel-like factor-4 (Klf4), insulin-like growth factor-1 (IGF-1), and IL-10 in the brain motor cortex tissues were evaluated using real-time PCR. Briefly, total RNA was extracted using an RNeasy mini kit (Qiagen). cDNA was synthesized from $2 \mathrm{mg}$ of total RNA with random hexamer primers and SuperScript III (Invitrogen, Thermo Fisher Scientific Inc.). Primers were designed with the UCSC Genome Bioinformatics and the NCBI database and are listed in Table 1. qRT-PCR was conducted with Fast SYBR green master mix (Applied Biosystems, Thermo Fisher Scientific Inc.) on a StepOne real-time PCR system (Applied Biosystems). All experiments were carried out in triplicate, and the expression of each gene was normalized to endogenous GAPDH mRNA and calculated as the relative fold change compared to the control groups.

Table 1. Primer sequences used for real-time PCR gene expression analysis.

\begin{tabular}{ccc}
\hline Gene & Forward $\left(\mathbf{5}^{\prime} \mathbf{- 3}^{\prime} \mathbf{)}\right.$ & Reverse \\
\hline Tet1 & GGCTTGCAGACACTGATGAA & GAAACACAGTCGCCTCTTCC \\
Tet2 & GGGGTTGGAGCAAGTACAAA & CGGGTGTGTGTCATTTGAAG \\
Tet3 & AGTGGGTGATCCGAAGACAC & GCCAGGATCAAGATGACGAT \\
DNMT1 & GTGTGCGGGAATGTGCTCGCT & CAGTGGTGGTGGCACAGCGT \\
DNMT3a & AGCAAAGTGAGGACCATTACCACCA & TGTGTAGTGGACAGGGAAGCCA \\
TNF- $\alpha$ & CTCAAGCCCTGGTATGAGCC & GGCTGGGTAGAGAACGGATG \\
IL-6 & ACCACCCACAACAGACCAGT & CAGAATTGCCATTGCACAAC \\
IL-1 $\beta$ & CACCTCTCAAGCAGAGCACAG & GGGTTCCATGGTGAAGTCAAC \\
Klf4 & CTTTCCTGCCAGACCAGATG & GGTTTCTCGCCTGTGTGAGT \\
Igf1 & CACACTGACATGCCCAAGAC & GGGAGGCTCCTCCTACATTC \\
IL-10 & CAGCTGCGACGCTGTCATCG & GCAGTCCAGTAGATGCCGGGT \\
18 s rRNA & CACTGAGCATCTCCCTCACA & GAGGGTGCAGCGAACTTTAT \\
\hline
\end{tabular}

\subsection{Functional Assessments}

We used two methods for assessments of the locomotor recovery of paralyzed hindlimbs after SCI, namely, the Basso, Beattie, and Bresnahan (BBB) locomotor rating scale and the horizontal ladder walk test ( $n=13$ in the control group and $n=14$ in the exercise group). The BBB scale ranges from 0 points (no hindlimb movement) to 21 points (normal hindlimb movement) [31]. Two examiners observed hindlimb movements for $4 \mathrm{~min}$ in the open field (cylindrical-shaped acrylic box, $90 \mathrm{~cm}$ in diameter and $15 \mathrm{~cm}$ high, with a smooth floor). In the horizontal ladder test, the rats were trained several times for adaptation before testing. The rats run across a $127 \mathrm{~cm}$ long horizontal runway made from $3 \mathrm{~mm}$ diameter metal rungs with a minimum distance of $1 \mathrm{~cm}$ and two $10 \mathrm{~cm}$ tall acrylic sidewalls. The test was 
video recorded and analyzed in slow motion using a digital camcorder. The ladder score was presented as the percentage of erroneous steps among the total hindlimb steps [32]. The locomotor function of each group was examined every 7 days until the date of sacrifice.

Evaluations of bladder function and urodynamic studies (UDS) were performed according to previous studies $[25,33,34]$. Briefly, the rats were anesthetized with isoflurane, and an incision was made to expose the bladder. A 4-Fr double-lumen polyethylene catheter was used to connect the bladder to a pressure transducer, and an infusion pump (KDS100; KD Scientific Inc., Holliston, MA, USA) loaded with a normal saline-filled syringe. The pressure signal was amplified and recorded using LabChart software (PowerLab 8/30 with LabChart Pro; AD Instruments, Colorado Springs, CO, USA), and the measured parameters were the maximal micturition pressure $\left(\mathrm{cmH}_{2} \mathrm{O}\right)$ and frequency (time/min), the gross voiding patterns, and the regularity of the micturition pressure and frequency. Immediately before UDS, the diameter of the exposed bladder dome was measured for indirect evaluation of bladder hypertrophy. The bladder volume was calculated as an imaginary sphere as follows: bladder volume $=(\text { horizontal diameter of the bladder } / 2)^{2} \times$ vertical diameter of the bladder $/ 2 \times \pi \times 4 / 3$.

\subsection{Statistics}

All numerical data are reported as the means \pm standard deviations, and IBM SPSS Statistics 25 (IBM, Armonk, NY, USA) was used for analysis. The Shapiro-Wilk test was performed to check the normal distribution of all quantified histological and functional data from each group, and according to the results, a nonparametric test was chosen. For histological, immunohistochemical, DNA dot blot, and quantitative PCR data, the MannWhitney $\mathrm{U}$ test was performed to compare data between the control and exercise groups. Repeated measures two-way analysis of variance was used to compare locomotor function for 12 weeks, including the BBB and ladder tests, between the control and exercise groups followed by Bonferroni test for comparison between two groups at each time point. Effects were considered significant at $p<0.05$

\section{Results}

\subsection{Treadmill Exercise Reduces the Lesion Cavity and Inflammatory Response after SCI}

We measured the size of lesion cavities via H\&E staining of injured spinal cord tissue and found that the cavity size of the control group without exercise was larger than that of the experimental group, which performed exercise until the time of sacrifice $\left(3.00 \pm 0.58 \mathrm{~mm}^{2}\right.$ and $1.62 \pm 0.08 \mathrm{~mm}^{2}$, respectively, Figure 2a,c). The number of ED1-positive cells within the lesioned epicenter was also higher in the control group one in the 12 weeks exercise group after injury (1429.0 \pm 395.6 and $735.8 \pm 140.2$, respectively, Figure $2 b$,d).

a

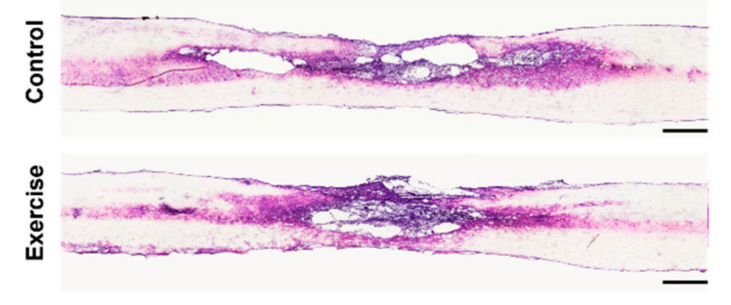

b

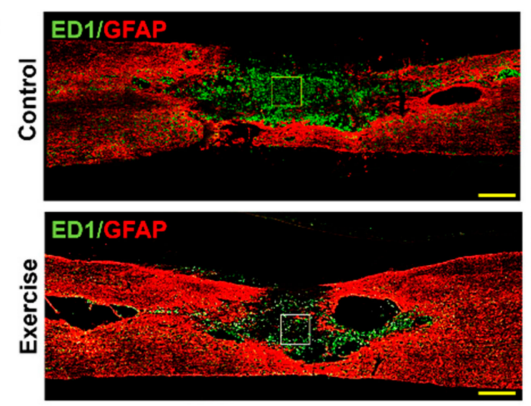

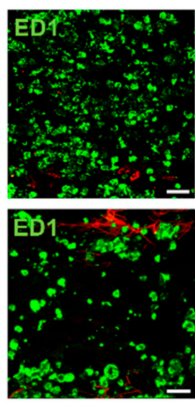

Figure 2. Cont. 
C

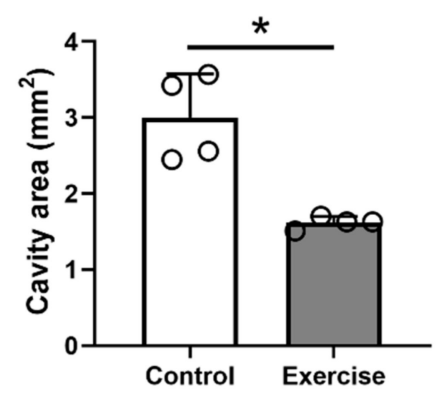

d

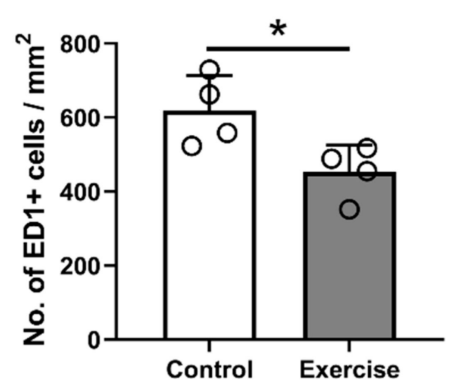

Figure 2. Histological analysis of the injured spinal cords at 12 weeks after injury. Representative images of (a) H\&E staining and (b) immunofluorescent staining for ED1 (green) and GFAP (red) in the control and exercise groups. (c) The cavity area measured from the sagittal images of H\&E staining ( $n=4$ per group). (d) Number of ED1-positive macrophages counted in the lesion area from immunohistochemical staining ( $n=4$ per group). ${ }^{*} p<0.05$ between the control and exercise groups by the Mann-Whitney $\mathrm{U}$ test. Black and yellow scale bars $=500 \mu \mathrm{m}$, white scale bar $=100 \mu \mathrm{m}$.

\subsection{Treadmill Exercise Modulates DNA Methylation and Hydroxymethylation in the Brain Motor Cortex after SCI}

We investigated DNA methylation changes in the brain motor cortex at 12 weeks after injury in both the control and exercise groups. $5 \mathrm{mC}$ and $5 \mathrm{hmC}$ within neurons in the brain motor cortex were identified using immunohistochemical double-staining (anti-NeuN and anti-5mC antibodies, or anti-NeuN and anti-5hmC antibodies) (Figure $3 \mathrm{a}, \mathrm{b}$ ), and we found that the anti-5mC and anti-5hmC intensities within NeuN-positive neurons were higher in the exercise group than those in the control group $(1.65 \pm 0.43$ and $3.77 \pm 0.72$ for anti- $5 \mathrm{mC}$ intensity, and $1.76 \pm 0.18$ and $3.21 \pm 0.75$ for anti-5hmC intensity, respectively, Figure $3 c, d$ ).

Additionally, the amounts of $5 \mathrm{mC}$ and $5 \mathrm{hmC}$ in genomic DNA extracted from the brain motor cortex were analyzed using DNA dot blot assay (Figure 3e). We found that the $5 \mathrm{mC}$ and $5 \mathrm{hmC}$ levels in $250 \mathrm{ng}$ of genomic DNA were significantly higher in the exercise group than those in the control group $(2.75 \pm 0.27$ for $5 \mathrm{mC}$ and $4.97 \pm 0.76$ for $5 \mathrm{hmC}$ in the exercise group, Figure 3f).

Tet enzymes catalyze the conversion of $5 \mathrm{mC}$ to $5 \mathrm{hmC}$, and further conversion of $5 \mathrm{hmC}$ to 5 -formylcytosine $(5 \mathrm{fC})$ and then to 5 -carboxycytosine $(5 \mathrm{caC})$. We, therefore, identified whether the increase in $5 \mathrm{hmC}$ after exercise training was associated with the Tets. Neurons in the brain motor cortex were triple-stained with anti-5hmC, anti-NeuN, and one of three different anti-Tet isoforms (TET1, 2, and 3) antibodies (Figure 4a-c. We found that the anti-Tet1, anti-Tet2, and anti-Tet3 intensities of the exercise group were significantly higher than those of the control group $(1.25 \pm 0.56$ and $3.47 \pm 0.87$ for anti-Tet1 intensity, $1.10 \pm 0.64$ and $4.16 \pm 0.64$ for anti-Tet2 intensity, $1.73 \pm 0.30$ and $4.77 \pm 1.41$ for anti-Tet3 intensity, respectively, Figure $4 d-f$.
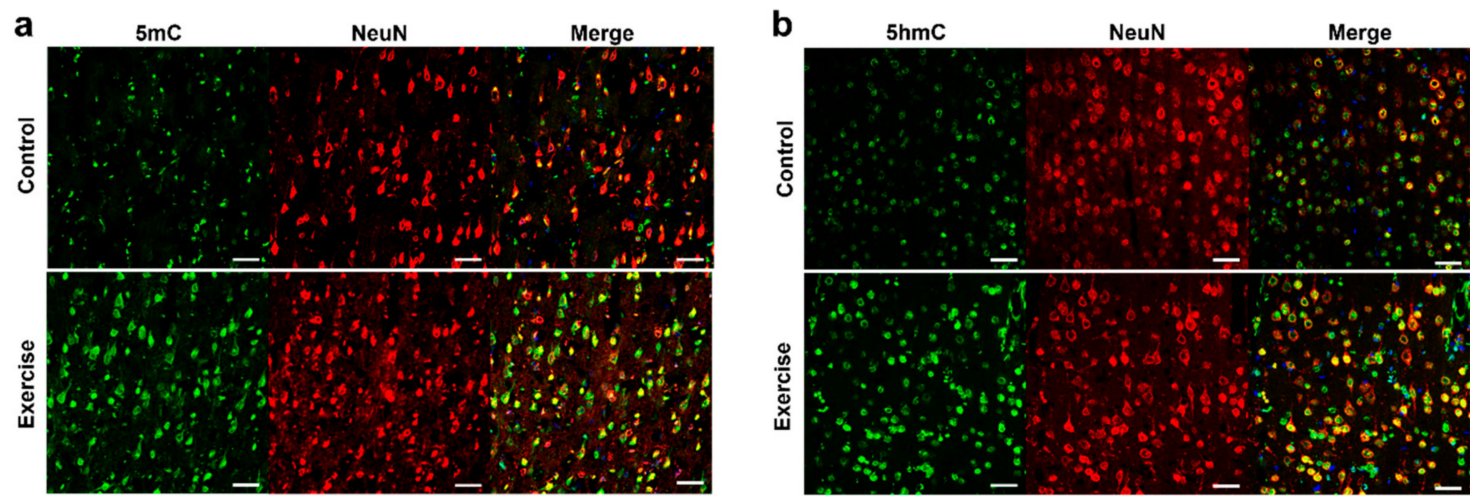

Figure 3. Cont. 
C

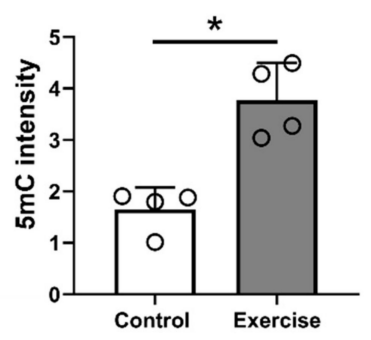

e

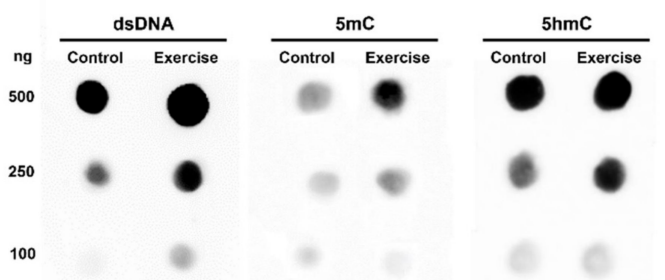

d
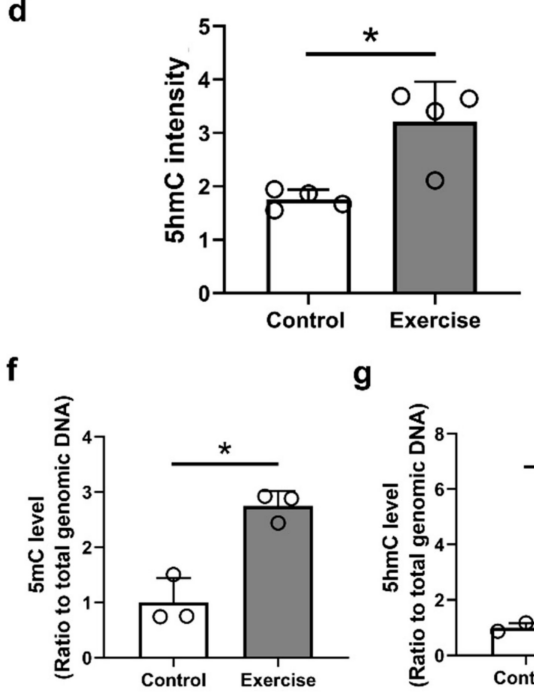

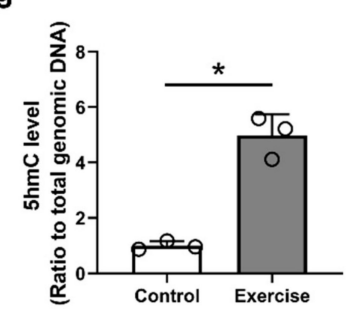

Figure 3. Epigenetic changes in the brain at 12 weeks after injury. Representative immunofluorescent images of double staining of (a) $5 \mathrm{mC}$ (green) and NeuN (red) and (b) $5 \mathrm{hmC}$ (green) and NeuN (red) in the primary motor cortex of the control and exercise groups. (c) $5 \mathrm{mC}$ and (d) $5 \mathrm{hmC}$ intensity in neurons in the primary motor cortex of the control and exercise groups ( $n=4$ per group). (e) Representative dot blot results for the primary motor cortex with 100, 250, and $500 \mathrm{ng}$ of $5 \mathrm{mC}$ and $5 \mathrm{hmC}$ in the control and exercise groups. Quantitative data from dot-blot analysis of $250 \mathrm{ng}$ of (f) $5 \mathrm{mC}$ and (g) $5 \mathrm{hmC}$ compared with the amount in total genomic DNA in the control and exercise groups. ${ }^{*} p<0.05$ between the control and exercise groups by the Mann-Whitney U test. White scale bars $=50 \mu \mathrm{m}$.

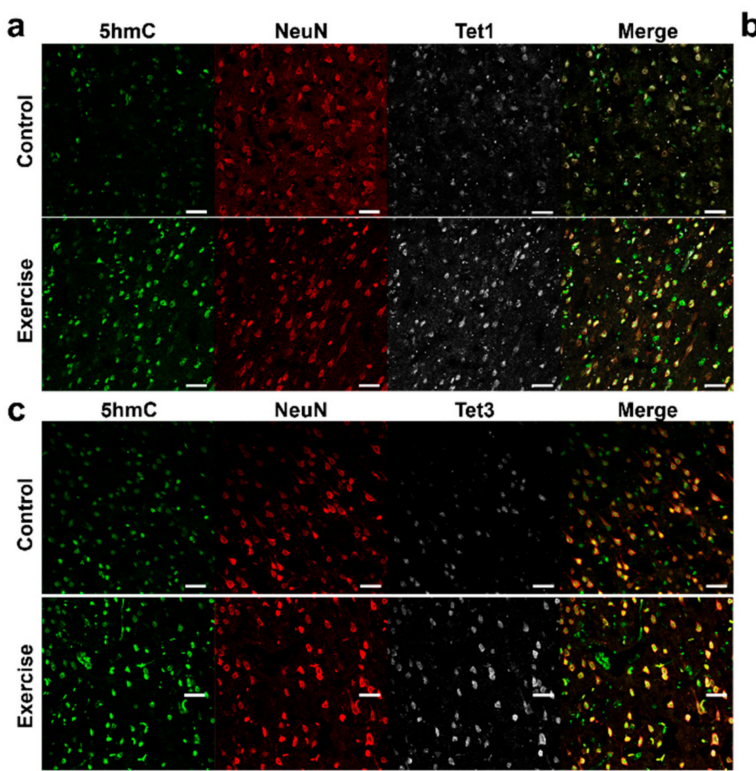

d

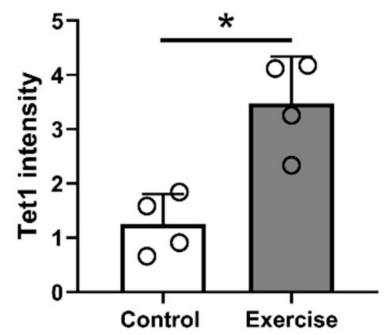

$\mathbf{e}$

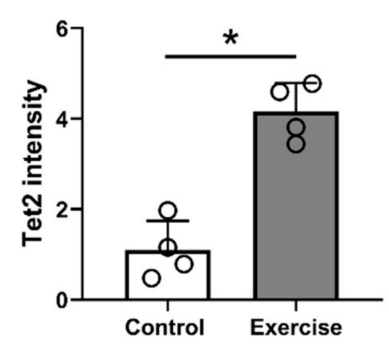

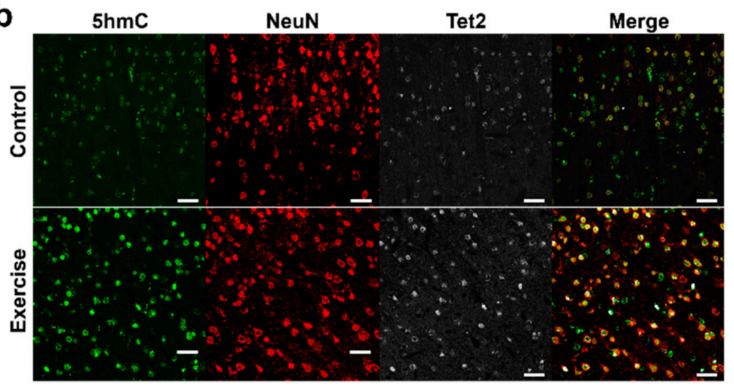

f

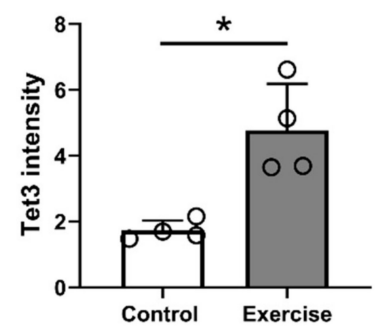

Figure 4. Representative immunofluorescent images showing triple staining of 5hmC (green), NeuN (red) and (a) Tet1 (gray), (b) Tet2 (gray), or (c) Tet3 (gray) in the primary motor cortex 12 weeks after injury in the control and exercise groups. (d) Tet1, (e) Tet2 and (f) Tet3 intensity of 5hmC-stained neurons in the primary motor cortexes of rats in the control and exercise groups ( $n=4$ per group). ${ }^{*} p<0.05$ between the control and exercise groups by Mann-Whitney $\mathrm{U}$ test. White scale bars $=50 \mu \mathrm{m}$. 


\subsection{Treadmill Exercise Promotes Axonal Regeneration and Sprouting, but Do Not Affect Macrophage Polarization in the Lesion Cavity after SCI}

We found that NF200-positive axons within the lesion cavity were increased in the exercise group more than in the control group (Figure 5a), and the density of NF200-positive axons was also higher in the exercise group than in the control group $(0.083 \pm 0.006$ for the control group and $0.167 \pm 0.018$ for the exercise group, Figure $5 b$ ). We also found that 5HT-positive axons were increased more around the lesion cavity in the exercise group than in the control group $(0.24 \pm 0.25$ for the control group and $1.06 \pm 0.36$ for the exercise group, Figure $5 \mathrm{c}, \mathrm{d}$ ). These findings suggest treadmill exercise may enhance axonal regeneration and sprouting in SCI models.

a

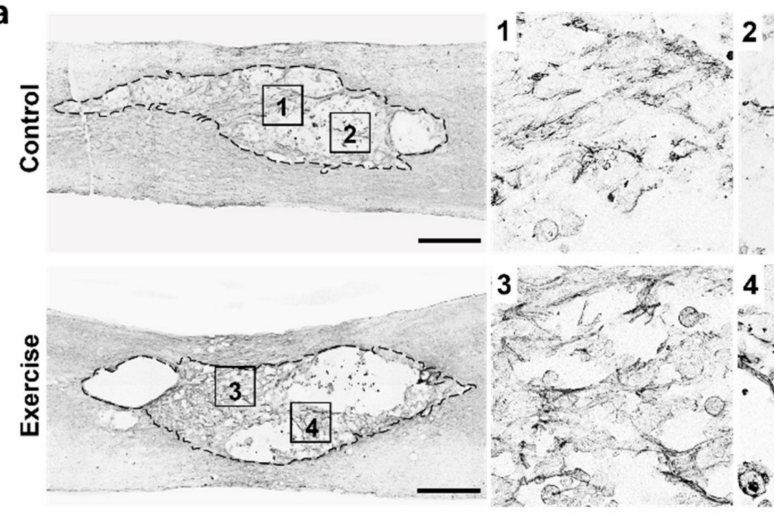

C

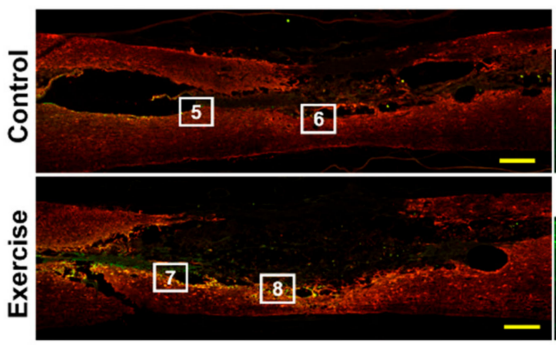

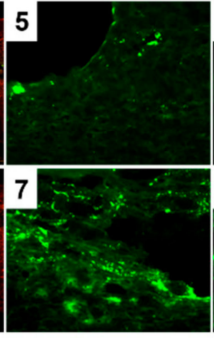
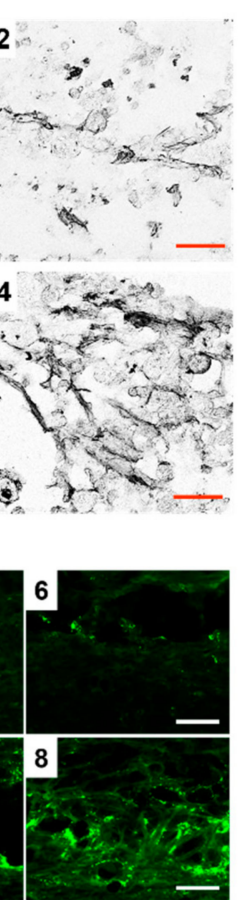

b

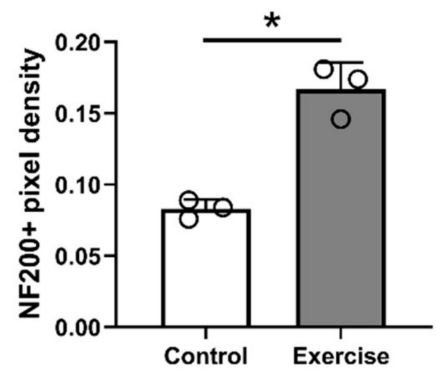

d

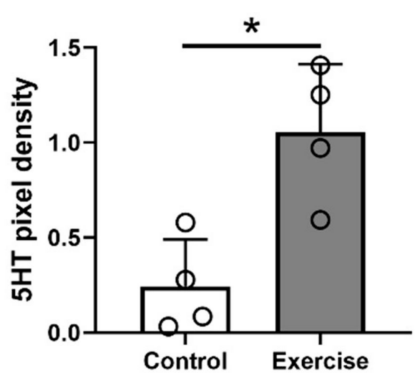

Figure 5. NF200 DAB staining results (a,b) and 5HT immunohistochemical results (c,d) in the injured spinal cord tissue at 12 weeks after injury (a-d). (a) Representative images of NF200-positive axons in the control and exercise groups. The right images are high-magnification images of the black boxes in the left images (Nos. 1-4) within the lesion cavities of contused spinal cords (outlined by black dashed lines). (b) The density of NF200-positive axons of the control and exercise groups ( $n=4$ per group). (c) Representative images of 5HT-positive axons (green) and GFAP-positive astrocytes (red) in the control and exercise groups. The right images are high-magnification images of the black boxes in the left images (Nos. 5-8) adjacent to the lesion cavities of contused spinal cords. (d) The density of 5HT-positive axons of the control and exercise groups ( $n=4$ per group). ${ }^{*} p<0.05$ between the control and exercise groups by Mann-Whitney U test. Black and yellow scale bars $=500 \mu \mathrm{m}$, white scale bar $=100 \mu \mathrm{m}$, red scale bar $=50 \mu \mathrm{m}$.

We performed double-staining with anti-CD86 and anti-ED1 antibodies for the detection of M1 macrophages, and anti-Arg1 and anti-ED1 antibodies for the detection of M2 macrophages in injured spinal cord tissue at 12 weeks after injury (Figure 6a-d. The overall numbers of ED1-positive macrophages were smaller in the exercise group, as previously described; however, the proportion of CD86- and Arg1-positive macrophages to total (ED1-positive) macrophages was not significantly different between the control and exercise groups (Figure 6e,f). 
a

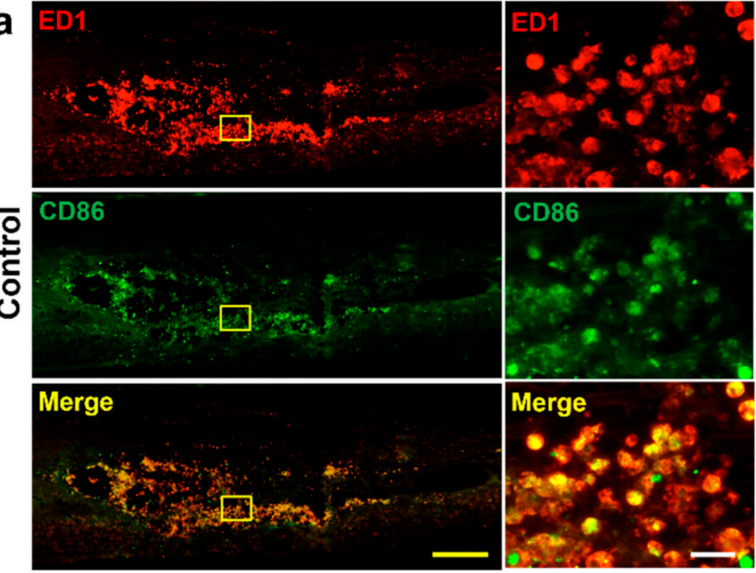

C

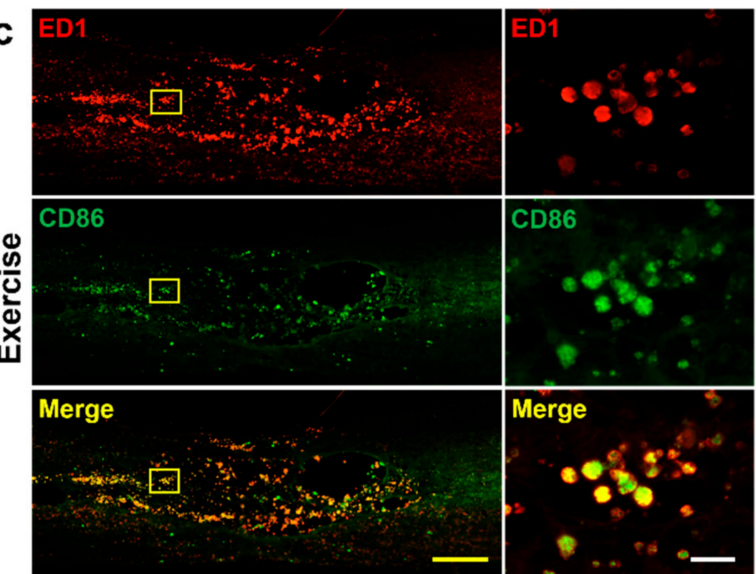

e

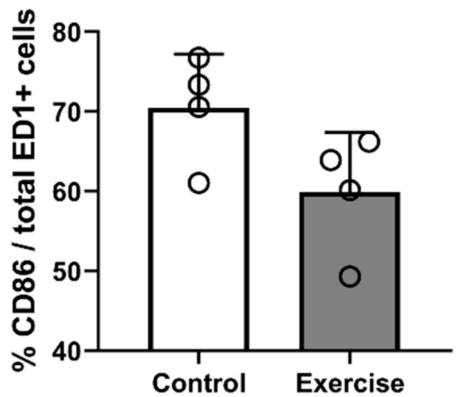

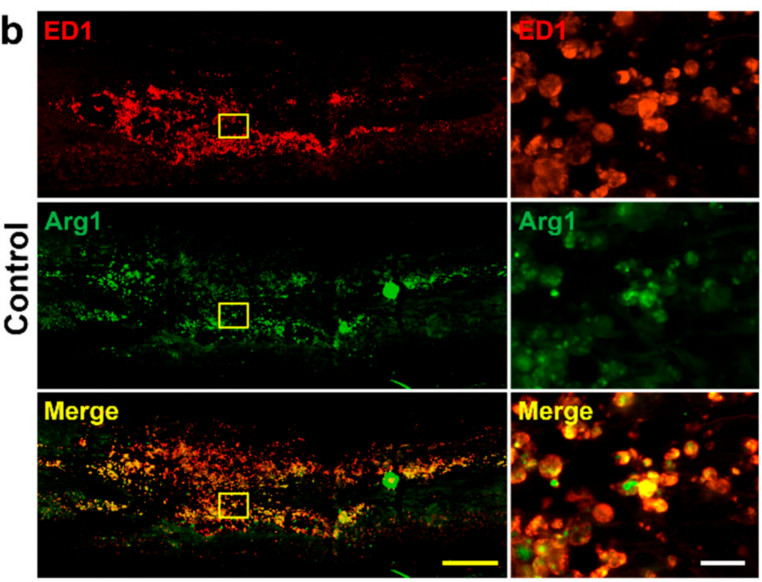

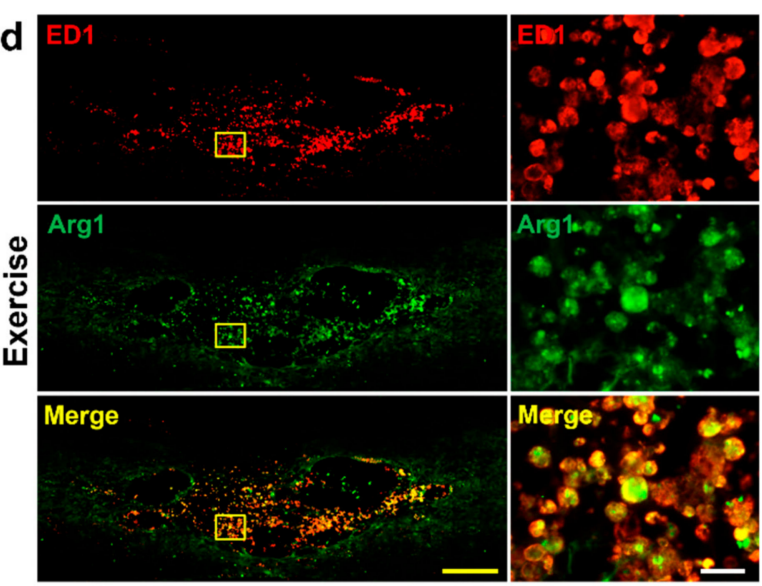

$\mathbf{f}$

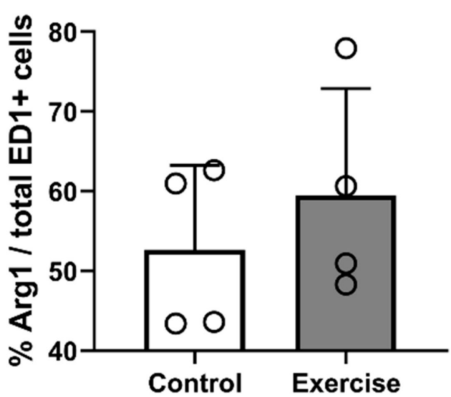

Figure 6. Immunofluorescent findings related to macrophage M1/M2 polarization 12 weeks after injury. (a) Representative images of CD68- and ED1-positive M1 macrophages and (b) Arg1- and ED1-positive M2 macrophages in the control group and (c) CD68- and ED1-positive M1 macrophages and (d) Arg1- and ED1-positive M2 macrophages in the exercise group. (e) Number of cells positive for (e) CD86 and (f) Arg1, normalized to ED1-positive cells ( $n=4$ per group). $p<0.05$ between the control and exercise groups by the Mann-Whitney $U$ test. Yellow scale bar $=500 \mu \mathrm{m}$, white scale bar $=50 \mu \mathrm{m}$.

We analyzed the changes in gene expression after exercise in SCI models using qRTPCR analysis (Figure 7). The expression levels of Tet1, Tet2, and Tet3 were all increased in the exercise group compared to the control group (Figure $7 \mathrm{a}-\mathrm{c}$, and the expression levels of different DNA methyltransferase genes (DNMT1a and DNMT3) were also increased in the exercise group (Figure 7d,e). The expression levels of inflammation-related genes (TNF $\alpha$, IL-6, and IL-1 $\beta$ ) were not different between the control and exercise groups (Figure $7 \mathrm{f}-\mathrm{h}$, and one of the regeneration-related genes, Igf1, was increased in the exercise group (Figure 7j), whereas Klf4 and IL-10 were not different between the control and exercise groups (Figure 7i,k). 
a

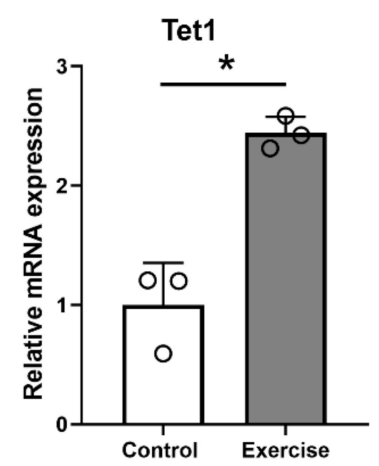

d

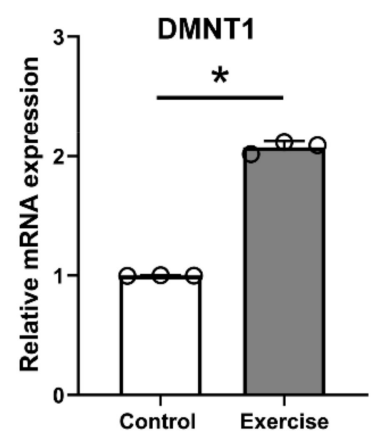

f

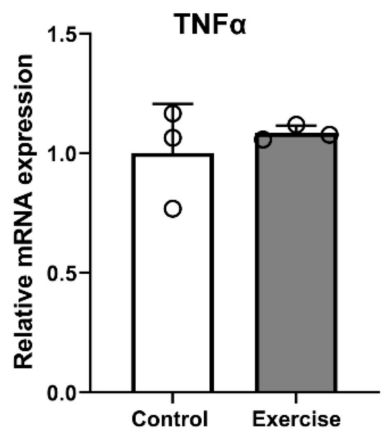

i

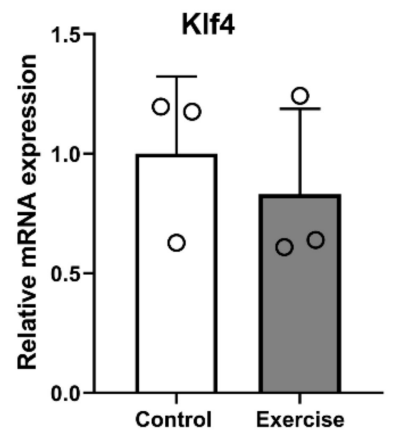

b

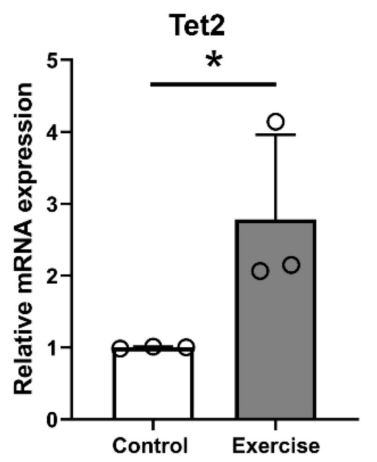

e

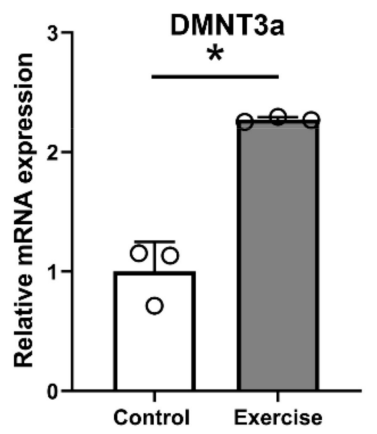

g

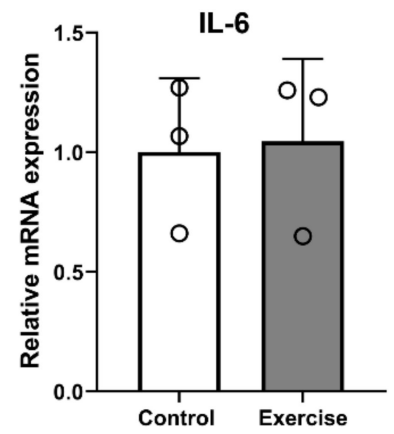

j

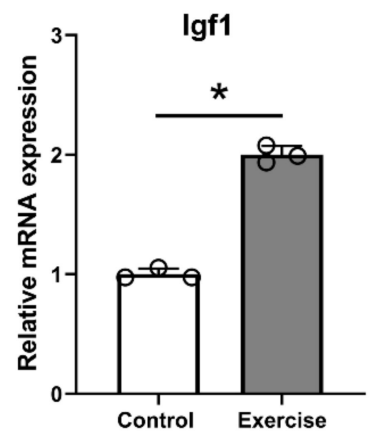

c

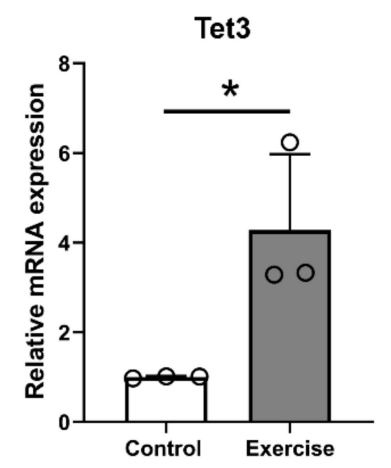

h

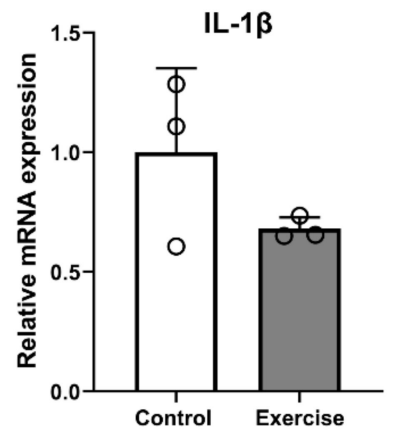

IL-10

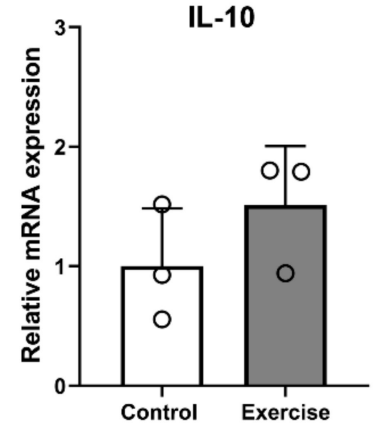

Figure 7. Real-time PCR analysis in the primary motor cortex of the control and exercise groups at 12 weeks after injury. $(\mathbf{a}-\mathbf{c})$ Tet family genes (Tet1, Tet2, and Tet3), (d,e) DNA methyltransferase genes (DNMT1, DNMT3a), (f-h) inflammationrelated genes (TNF $\alpha, \mathrm{IL}-6$, and IL-1 $\beta$ ), and (i-k) regeneration-related genes (Klf4, Igf1, IL-10) ( $n=3$ per group). ${ }^{*} p<0.05$ between the control and exercise groups by the Mann-Whitney U test.

\subsection{Treadmill Exercise Promotes Functional Improvement, but Do Not Modulate Neurogenic Bladder after SCI}

Locomotor function was assessed by measuring BBB and ladder scores. The BBB score was higher in the exercise group than in the control group from 4 weeks after injury to the time of sacrifice, and the final scores at 12 weeks after injury were $11.1 \pm 0.5$ and $12.5 \pm 0.8$ in the control and exercise groups, respectively (Figure 8a). The ladder score showed a better recovery pattern in the exercise group from 2 weeks after injury to the time of sacrifice, 
and the final scores at 12 weeks after injury were $23.8 \pm 5.8$ and $17.2 \pm 4.8$, respectively, in the control and exercise groups (Figure 8 b). The bladder volume, and bladder functions, which were evaluated using urodynamic study, showed typical hyperreflexic pattern; increased frequency and maximal pressure 12 weeks after SCI (Figure 8c), and the exercise group showed similar bladder volume and hyperreflexic voiding pattern without any improvement (Figure 8c).
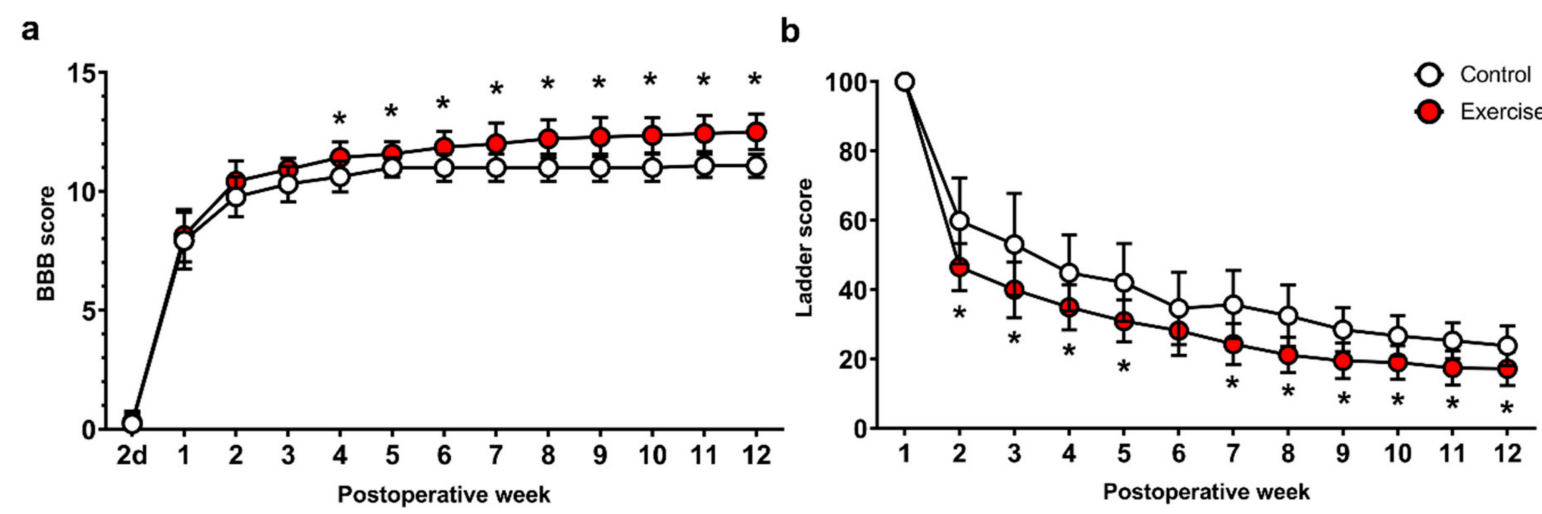

C

\begin{tabular}{ccc}
\hline & Control & Exercise \\
\hline Bladder volume $\left(\mathrm{mm}^{3}\right)$ & $1339.55 \pm 477.40$ & $1162.88 \pm 462.43$ \\
Micturition frequency $(\mathrm{min}-1)$ & $1.20 \pm 0.51$ & $1.04 \pm 0.23$ \\
Maximal pressure $(\mathrm{cmH} 2 \mathrm{O})$ & $35.61 \pm 7.36$ & $37.81 \pm 2.75$ \\
Pattern of reqularity $(\%)$ & & \\
Frequency & 100 & 100 \\
Pressure & 50 & 50 \\
Gross voiding pattern $(\%)$ & 0 & 0 \\
Flaccid & 100 & 100 \\
Hyperreflexia & 0 & 0 \\
Normal & & \\
\hline
\end{tabular}

Figure 8. Functional recovery of spinal cord-contused rats in the control and exercise groups. The locomotor functions of rats with SCI were analyzed using (a) Basso, Beattie, and Bresnahan (BBB) scores and (b) horizontal ladder tests during the 12-week experimental period ( $n=13$ for the control group, and $n=14$ for the exercise group). (c) The results of the urodynamic study and measurement of bladder volume at 12 weeks after injury ( $n=6$ per group). ${ }^{*} p<0.05$ between the control and exercise groups by repeated-measures two-way ANOVA followed by Bonferroni test at each time point.

\section{Discussion}

We found that genes and pathways associated with DNA methylation and hydroxymethylation, including $5 \mathrm{mC}, 5 \mathrm{hmC}$, Tet1, Tet2, Tet3, DNMT1, and DNMT3a, were activated in the brain motor cortex after treadmill exercise during the 12-week period following SCI (Figures 3, 4 and 7). DNMT1 and DNMT3a are members of the family of DNA methyltransferase enzymes that convert cytosine to $5 \mathrm{mC}$, and $5 \mathrm{mC}$ is hydroxylated into $5 \mathrm{hmC}$ by Tet1, Tet2, and Tet3 $[35,36]$. Therefore, in our study, treadmill exercise promoted the methylation and hydroxymethylation of cytosine in the brain motor cortex.

The roles of $5 \mathrm{mC}$ and $5 \mathrm{hmC}$ in the hippocampus were partially uncovered [17,37]. Jessop et al. found that Tet 1 and Tet2 expressions in the hippocampus were decreased in aged mice, and voluntary exercise for five weeks induced increases in Tet1 and Tet2 expression and 5hmC levels; memory function was also improved [17]. In addition, DNA methylation may increase gene expression related to neuronal plasticity and improve memory and cognitive function in the hippocampus [37]. Enhanced DNA methylation, increased $5 \mathrm{mC}$ levels, and DNMT1 activity induced by maternal supplementation with folic acid were also shown to improve the early development of motor and sensory functions in rat offspring [38]. Previously we showed that $5 \mathrm{mC}$ levels in genomic DNA were increased in the acute and subacute stages; $5 \mathrm{hmC}$ levels in genomic DNA, and mRNA expression levels of Tet1, Tet2, and Tet3 were also increased from the acute to the chronic stage 
in the brain motor cortex after SCI [11]. Therefore, increased DNA methylation and hydroxymethylation in the brain motor cortex may provide a chance to enhance the neuronal plasticity of damaged corticospinal tracts in the lesioned spinal cord.

Axonal regeneration after SCI is thought to be closely related to changes in DNA methylation and hydroxymethylation, and these changes appear differently depending on the type of gene in the spinal cord [39]. The brain motor cortex is the location of the cell body of the corticospinal tracts and is also important for controlling hindlimb activity during locomotion in cats and rats [40,41]. The motor cortex also influences motor recovery following neuromodulation [42] and reorganizes substantially following task-specific tasking after SCI [43].

Epigenetic changes in the brain motor cortex following exercise after SCI were not evident in a previous study; however, several notable results have been found in skeletal muscles and the brain in previous studies [12-16]. The gene expression changes that occur following exercise are not clearly regulated by DNA methylation, but relative DNA hypomethylation of key metabolic and regulatory genes in skeletal muscle may be associated with exercise training [12]. Although the global change of DNA methylation has been examined in other studies, the results are different according to the type and duration of exercise training, and since DNA methylation or demethylation is related to individual gene changes, it is necessary to determine the changes for each gene $[13,14]$. Moreover, various epigenetic changes are already known to occur after trauma or disease in the central nervous system [44], and it is very difficult to predict additional epigenetic changes after exercise. Our previous study revealed that global DNA methylation and hydroxymethylation in the brain motor cortex were increased according to the duration after SCI, and ascorbic acid enhanced $5 \mathrm{mC}$ and $5 \mathrm{hmC}$ formation within the brain motor cortex at three months after application, with a concomitant functional improvement [11]. Sun et al. also found that $5 \mathrm{hmC}$ was increased in spinal cord tissue during the acute stage after SCI, and inhibition of Tet2 exacerbated necrosis within the lesioned spinal cord, although no epigenetic changes within the brain were reported [45].

Studies have reported the effectiveness of exercise training in spinal cord injury in animal models, and humans, especially for the functional restoration and control of neuropathic pain [46-49], and that axonal sprouting and synaptic plasticity were increased after treadmill exercise in SCI rodents [47,50]. DNA methylation is also important for facilitating synaptic plasticity [51], and inhibition of DNA methylation induced the impairment of long-term hippocampal potentiation in rats in a previous study [52]. We found that NF200-positive axons exhibited more outgrowth within the lesion cavity (Figure 5a,b), and 5HT-positive axons, which might represent axonal sprouting after SCI, were visible more around the lesion cavity (Figure $5 \mathrm{c}, \mathrm{d}$ ) in the spinal cord in exercise-treated rats than in the control rats although synaptic plasticity was not investigated in this study. In addition to axonal regeneration, axonal sprouting caudal to the injured spinal cord may be related to functional improvement in SCI [53], and some treatments that induce 5HT axonal sprouting have successfully promoted functional recovery after SCI in previous studies [54,55]. As shown in the results in this study, locomotor functions, which were evaluated using BBB and ladder scores, were also improved during the 12-week experimental period (Figure 8).

Bladder function is frequently disrupted in SCI patients, and neurogenic bladder causes urinary tract infection, incontinence, urinary stones, and poor quality of life. The most frequent bladder dysfunctions observed in thoracic SCI patients are detrusor hyperreflexia and detrusor-sphincter dyssynergia [56], and thoracic spinal cord-contused rats also showed the same pattern in our previous studies [33,34]. Previously, forelimb exercise training was shown to reduce maximal pressure during bladder contraction using awake cystometry, and whole-body vibration was effective in minimizing incontinence [57]. In our previous study using sham-operated controls, bladder volume was $564.54 \pm 134.01 \mathrm{~mm}^{3}$, micturition frequency was $0.60 \pm 0.21 / \mathrm{min}$, maximal pressure was $26.81 \pm 5.81 \mathrm{cmH}_{2} \mathrm{O}$, and gross voiding pattern was normal [33]. Therefore, when compared with the values of the previous study, bladder volume, voiding frequency and maximal pressure, and detrusor 
hyperreflexia after SCI were not recovered in both the control and exercise groups (Figure 8b); therefore, we could not find any improvements in bladder dysfunction in the exercise group. More than three-quarters of all SCI patients cannot void volitionally [58], and the recovery of bladder function is more complex than that of hindlimb locomotion, as it involves somatic and autonomic pathways that are disrupted or deactivated after SCI. Further study of bladder recovery after SCI is needed to obtain an effective treatment.

Previous studies have revealed macrophage changes after exercise in SCI $[46,59]$. Chhaya et al. found that the number of macrophages in the dorsal root ganglion below the lesioned spinal cord was reduced early after 4-week exercise training, and neuropathic pain was also improved [46]. However, in another study, the number of microglia in the lumbar spinal cord after thoracic spinal cord contusion was not decreased, although the locomotor function was improved early after two weeks of treadmill exercise [59]. In this study, we found that numbers of macrophages and microglia in the lesioned spinal cord decreased in number after treadmill exercise (Figure 2b,d), while the ratio of M1/M2 macrophages and the levels of M2 macrophage-related IL-10 were not changed (Figure 6, Figure 7k). Some treatments modulating M2 polarization of macrophages and microglia have also shown functional restoration after SCI [29,60]; however, there has been no study revealing the relationship between M2 polarization and exercise after SCI, and the epigenetic mechanisms regulating M1/M2 polarization have not yet been determined [8].

Compared to a previous study using ascorbic acid, $100 \mathrm{mg} / \mathrm{kg}$ ascorbic acid and 11-week treadmill exercise showed similar patterns, with an increase in global DNA methylation, and some proinflammatory cytokines, such as IL-1 $\beta$ and TNF $\alpha$, were not changed in the brain motor cortex 12 weeks after SCI [11]. At the chronic stage after SCI, proinflammatory cytokines are usually downregulated, but our previous study showed the optimal concentration of ascorbic acid was effective in decreasing IL-6 [11], which was not found in this study. However, in order to clarify the effect of treadmill exercise on the proinflammatory cytokines as well as macrophage polarization, further study is necessary at the acute stage where the inflammatory process is maximum. Some regeneration-associated genes, including Klf4 and Igf1, showed opposite patterns of expression, and DNMT1 and DNMT3a gene expression after exercise was increased, whereas it was not changed after ascorbic acid application [11]. The Igf1 gene is a regeneration-associated gene that shows a neuroprotective effect against apoptosis, and treadmill exercise after SCI promoted the upregulation of Igf1 gene expression in previous studies [27,61], whereas Klf4 gene expression was downregulated following treadmill exercise [27]. Igf1 was effective in regrowth of corticospinal tracts after the application of osteopontin to spinal cord-injured mice in a previous study [62], and the upregulation of Igf1 expression after exercise may have contributed to axonal outgrowth in the corticospinal tract and functional restoration in this study. Klf4 gene is a reprogramming factor, and its overexpression combined with Oct4 overexpression improved BBB scores in SCI mice [63]; however, some researchers reported opposite findings. For example, Klf4-suppressed retinal ganglion cells showed an increase in axonal outgrowth [64], downregulation of Klf4 reduced the inflammatory response and enhanced functional outcomes in SCI rats [65], and deletion of Klf4 promoted axonal regeneration of the corticospinal tract in SCI mice [66]. Changes in the Igf1 and Klf4 genes after the application of ascorbic acid or treadmill exercise training may not be related to epigenetic changes, and further research is needed to reveal their relationships with functional improvements. The upregulation of DNMT1 and DNMT3a expression within the brain motor cortex is related to increased $5 \mathrm{mC}$ intensity and an increased amount of $5 \mathrm{mC}$ in genomic DNA in the 12 weeks exercise group after SCI. In our previous study, $5 \mathrm{mC}$ intensity was not increased after ascorbic acid application in the chronic stage [11]; therefore, treadmill exercise is more sustainably effective for DNA methylation than ascorbic acid. It is unclear whether these results are related to the persistence of the functional recovery effect after SCI, but it seems clear that our results show patterns of epigenetic changes that differ from those associated with ascorbic acid application. Therefore, combinations of drugs and exercise, which can be applied in the clinical setting for SCI patients, may have a syner- 
gistic effect in promoting functional restoration in SCI, and further studies will be planned. In addition, since several mechanisms including ERK1/2 activation, upregulation of various neurotrophic factors, and compensation mechanisms may contribute the effect of treadmill exercise on functional restoration after SCI, the effect of DNA methylation and demethylation in this study could not be identified separately from these mechanisms. Therefore, efforts to confirm the effect of epigenetic changes on functional restoration after exercise through additional experiments that inhibit DNA methylation or demethylation will be required.

\section{Conclusions}

In this study, we found that DNA hypermethylation was enhanced after treadmill exercise in the SCI rats, and treadmill exercise also facilitated functional recovery. We concluded that epigenetic changes in the brain motor cortex might contribute to exercise-induced functional improvements.

Author Contributions: Conceptualization, K.H. and J.K.H.; methodology, G.D. and J.K.H.; validation, G.D., J.Y.H. and J.K.H.; formal analysis, G.D. and J.K.H.; investigation, G.D., J.Y.H. and J.K.H.; data curation, G.D. and J.K.H.; writing — original draft preparation, G.D., J.Y.H. and J.K.H.; writing-review and editing, S.Y.K., S.J.L., T.U.K. K.H. and J.K.H.; visualization, G.D., J.Y.H. and J.K.H.; supervision, K.H. and J.K.H.; project administration, S.Y.K. and J.K.H.; funding acquisition, S.Y.K. and J.K.H. All authors have read and agreed to the published version of the manuscript.

Funding: This research was funded by the National Research Foundation (NRF) and the Ministry of Science and ICT (MSIT) in Korea, grant number 2018R1C1B6007133, 2019R1A6A1A11034536, and 2020R1A2C2004764.

Institutional Review Board Statement: The study was approved by Dankook University's Institutional Animal Care and Use Committee (Approval No. 19-009).

Informed Consent Statement: Not applicable.

Data Availability Statement: The data presented in this study are available on request from the corresponding author.

Conflicts of Interest: The authors declare no conflict of interest.

\section{References}

1. Barriere, G.; Leblond, H.; Provencher, J.; Rossignol, S. Prominent role of the spinal central pattern generator in the recovery of locomotion after partial spinal cord injuries. J. Neurosci. 2008, 28, 3976-3987. [CrossRef] [PubMed]

2. Martinez, M.; Delivet-Mongrain, H.; Leblond, H.; Rossignol, S. Recovery of hindlimb locomotion after incomplete spinal cord injury in the cat involves spontaneous compensatory changes within the spinal locomotor circuitry. J. Neurophysiol. 2011, 106, 1969-1984. [CrossRef] [PubMed]

3. Oh, M.J.; Seo, T.B.; Kwon, K.B.; Yoon, S.J.; Elzi, D.J.; Kim, B.G.; Namgung, U. Axonal outgrowth and Erk1/2 activation by training after spinal cord injury in rats. J. Neurotrauma 2009, 26, 2071-2082. [CrossRef] [PubMed]

4. Keeler, B.E.; Liu, G.; Siegfried, R.N.; Zhukareva, V.; Murray, M.; Houle, J.D. Acute and prolonged hindlimb exercise elicits different gene expression in motoneurons than sensory neurons after spinal cord injury. Brain Res. 2012, 1438, 8-21. [CrossRef] [PubMed]

5. Wang, H.; Liu, N.K.; Zhang, Y.P.; Deng, L.; Lu, Q.B.; Shields, C.B.; Walker, M.J.; Li, J.; Xu, X.M. Treadmill training induced lumbar motoneuron dendritic plasticity and behavior recovery in adult rats after a thoracic contusive spinal cord injury. Exp. Neurol. 2015, 271, 368-378. [CrossRef]

6. Ilha, J.; Meireles, A.; de Freitas, G.R.; do Espirito Santo, C.C.; Machado-Pereira, N.; Swarowsky, A.; Santos, A.R.S. Overground gait training promotes functional recovery and cortical neuroplasticity in an incomplete spinal cord injury model. Life Sci. 2019, 232, 116627. [CrossRef]

7. Liu, G.; Detloff, M.R.; Miller, K.N.; Santi, L.; Houle, J.D. Exercise modulates microRNAs that affect the PTEN/mTOR pathway in rats after spinal cord injury. Exp. Neurol. 2012, 233, 447-456. [CrossRef]

8. Wahane, S.; Halawani, D.; Zhou, X.; Zou, H. Epigenetic Regulation of Axon Regeneration and Glial Activation in Injury Responses. Front Genet. 2019, 10, 640. [CrossRef]

9. Hutson, T.H.; Kathe, C.; Palmisano, I.; Bartholdi, K.; Hervera, A.; De Virgiliis, F.; McLachlan, E.; Zhou, L.; Kong, G.; Barraud, Q.; et al. $\mathrm{Cbp}$-dependent histone acetylation mediates axon regeneration induced by environmental enrichment in rodent spinal cord injury models. Sci. Transl. Med. 2019, 11, eaaw2064. [CrossRef] 
10. Zheng, Z.; Zhou, Y.; Ye, L.; Lu, Q.; Zhang, K.; Zhang, J.; Xie, L.; Wu, Y.; Xu, K.; Zhang, H.; et al. Histone deacetylase 6 inhibition restores autophagic flux to promote functional recovery after spinal cord injury. Exp. Neurol. 2020, 324, 113138. [CrossRef]

11. Hong, J.Y.; Davaa, G.; Yoo, H.; Hong, K.; Hyun, J.K. Ascorbic Acid Promotes Functional Restoration after Spinal Cord Injury Partly by Epigenetic Modulation. Cells 2020, 9, 1310. [CrossRef] [PubMed]

12. McGee, S.L.; Hargreaves, M. Epigenetics and Exercise. Trends Endocrinol. Metab. 2019, 30, 636-645. [CrossRef] [PubMed]

13. Widmann, M.; Niess, A.M.; Munz, B. Physical Exercise and Epigenetic Modifications in Skeletal Muscle. Sports Med. 2019, 49, 509-523. [CrossRef] [PubMed]

14. Jacques, M.; Hiam, D.; Craig, J.; Barres, R.; Eynon, N.; Voisin, S. Epigenetic changes in healthy human skeletal muscle following exercise- a systematic review. Epigenetics 2019, 14, 633-648. [CrossRef] [PubMed]

15. Lovatel, G.A.; Elsner, V.R.; Bertoldi, K.; Vanzella, C.; Moyses Fdos, S.; Vizuete, A.; Spindler, C.; Cechinel, L.R.; Netto, C.A.; Muotri, A.R.; et al. Treadmill exercise induces age-related changes in aversive memory, neuroinflammatory and epigenetic processes in the rat hippocampus. Neurobiol. Learn. Mem. 2013, 101, 94-102. [CrossRef]

16. Spindler, C.; Cechinel, L.R.; Basso, C.; Moyses, F.; Bertoldi, K.; Roesler, R.; Lovatel, G.A.; Rostirola Elsner, V.; Siqueira, I.R. Treadmill exercise alters histone acetyltransferases and histone deacetylases activities in frontal cortices from wistar rats. Cell. Mol. Neurobiol. 2014, 34, 1097-1101. [CrossRef]

17. Jessop, P.; Toledo-Rodriguez, M. Hippocampal TET1 and TET2 Expression and DNA Hydroxymethylation are Affected by Physical Exercise in Aged Mice. Front. Cell Dev. Biol. 2018, 6, 45. [CrossRef]

18. Sandrow-Feinberg, H.R.; Houle, J.D. Exercise after spinal cord injury as an agent for neuroprotection, regeneration and rehabilitation. Brain Res. 2015, 1619, 12-21. [CrossRef]

19. Massoto, T.B.; Santos, A.C.R.; Ramalho, B.S.; Almeida, F.M.; Martinez, A.M.B.; Marques, S.A. Mesenchymal stem cells and treadmill training enhance function and promote tissue preservation after spinal cord injury. Brain Res. 2020, 1726, 146494. [CrossRef]

20. Tashiro, S.; Nishimura, S.; Iwai, H.; Sugai, K.; Zhang, L.; Shinozaki, M.; Iwanami, A.; Toyama, Y.; Liu, M.; Okano, H.; et al. Functional Recovery from Neural Stem/Progenitor Cell Transplantation Combined with Treadmill Training in Mice with Chronic Spinal Cord Injury. Sci. Rep. 2016, 6, 30898. [CrossRef]

21. Ganzer, P.D.; Beringer, C.R.; Shumsky, J.S.; Nwaobasi, C.; Moxon, K.A. Serotonin receptor and dendritic plasticity in the spinal cord mediated by chronic serotonergic pharmacotherapy combined with exercise following complete SCI in the adult rat. Exp. Neurol. 2018, 304, 132-142. [CrossRef] [PubMed]

22. Foffani, G.; Shumsky, J.; Knudsen, E.B.; Ganzer, P.D.; Moxon, K.A. Interactive Effects Between Exercise and Serotonergic Pharmacotherapy on Cortical Reorganization After Spinal Cord Injury. Neurorehabil. Neural Repair 2016, 30, 479-489. [CrossRef] [PubMed]

23. Endo, T.; Ajiki, T.; Inoue, H.; Kikuchi, M.; Yashiro, T.; Nakama, S.; Hoshino, Y.; Murakami, T.; Kobayashi, E. Early exercise in spinal cord injured rats induces allodynia through TrkB signaling. Biochem. Biophys. Res. Commun. 2009, 381, 339-344. [CrossRef] [PubMed]

24. Smith, R.R.; Brown, E.H.; Shum-Siu, A.; Whelan, A.; Burke, D.A.; Benton, R.L.; Magnuson, D.S. Swim training initiated acutely after spinal cord injury is ineffective and induces extravasation in and around the epicenter. J. Neurotrauma 2009, 26, 1017-1027. [CrossRef] [PubMed]

25. Hong, J.Y.; Lee, S.H.; Lee, S.C.; Kim, J.W.; Kim, K.P.; Kim, S.M.; Tapia, N.; Lim, K.T.; Kim, J.; Ahn, H.S.; et al. Therapeutic potential of induced neural stem cells for spinal cord injury. J. Biol. Chem. 2014, 289, 32512-32525. [CrossRef]

26. Hwang, D.H.; Park, H.H.; Shin, H.Y.; Cui, Y.; Kim, B.G. Insulin-like Growth Factor-1 Receptor Dictates Beneficial Effects of Treadmill Training by Regulating Survival and Migration of Neural Stem Cell Grafts in the Injured Spinal Cord. Exp. Neurobiol. 2018, 27, 489-507. [CrossRef]

27. Liu, Q.; Zhang, B.; Liu, C.; Zhao, D. Molecular mechanisms underlying the positive role of treadmill training in locomotor recovery after spinal cord injury. Spinal Cord 2017, 55, 441-446. [CrossRef]

28. Kim, J.W.; Mahapatra, C.; Hong, J.Y.; Kim, M.S.; Leong, K.W.; Kim, H.W.; Hyun, J.K. Functional Recovery of Contused Spinal Cord in Rat with the Injection of Optimal-Dosed Cerium Oxide Nanoparticles. Adv. Sci. (Weinh) 2017, 4, 1700034. [CrossRef]

29. Hong, J.Y.; Seo, Y.; Davaa, G.; Kim, H.W.; Kim, S.H.; Hyun, J.K. Decellularized brain matrix enhances macrophage polarization and functional improvements in rat spinal cord injury. Acta Biomater. 2020, 101, 357-371. [CrossRef]

30. DePaul, M.A.; Lin, C.Y.; Silver, J.; Lee, Y.S. Combinatory repair strategy to promote axon regeneration and functional recovery after chronic spinal cord injury. Sci. Rep. 2017, 7, 9018. [CrossRef]

31. Basso, D.M.; Beattie, M.S.; Bresnahan, J.C. Graded histological and locomotor outcomes after spinal cord contusion using the NYU weight-drop device versus transection. Exp. Neurol. 1996, 139, 244-256. [CrossRef] [PubMed]

32. Fouad, K.; Klusman, I.; Schwab, M.E. Regenerating corticospinal fibers in the Marmoset (Callitrix jacchus) after spinal cord lesion and treatment with the anti-Nogo-A antibody IN-1. Eur. J. Neurosci. 2004, 20, 2479-2482. [CrossRef] [PubMed]

33. Hyun, J.K.; Lee, Y.I.; Son, Y.J.; Park, J.S. Serial changes in bladder, locomotion, and levels of neurotrophic factors in rats with spinal cord contusion. J. Neurotrauma 2009, 26, 1773-1782. [CrossRef] [PubMed]

34. Park, W.B.; Kim, S.Y.; Lee, S.H.; Kim, H.W.; Park, J.S.; Hyun, J.K. The effect of mesenchymal stem cell transplantation on the recovery of bladder and hindlimb function after spinal cord contusion in rats. BMC Neurosci. 2010, 11, 119. [CrossRef] [PubMed]

35. Veron, N.; Peters, A.H. Epigenetics: Tet proteins in the limelight. Nature 2011, 473, 293-294. [CrossRef] [PubMed] 
36. Carey, N.; Marques, C.J.; Reik, W. DNA demethylases: A new epigenetic frontier in drug discovery. Drug Discov. Today 2011, 16, 683-690. [CrossRef] [PubMed]

37. Fernandes, J.; Arida, R.M.; Gomez-Pinilla, F. Physical exercise as an epigenetic modulator of brain plasticity and cognition. Neurosci. Biobehav. Rev. 2017, 80, 443-456. [CrossRef]

38. Li, W.; Li, Z.; Li, S.; Wang, X.; Wilson, J.X.; Huang, G. Periconceptional Folic Acid Supplementation Benefit to Development of Early Sensory-Motor Function through Increase DNA Methylation in Rat Offspring. Nutrients 2018, 10, 292. [CrossRef]

39. Madrid, A.; Borth, L.E.; Hogan, K.J.; Hariharan, N.; Papale, L.A.; Alisch, R.S.; Iskandar, B.J. DNA methylation and hydroxymethylation have distinct genome-wide profiles related to axonal regeneration. Epigenetics 2020, 1-15. [CrossRef]

40. Bretzner, F.; Drew, T. Contribution of the motor cortex to the structure and the timing of hindlimb locomotion in the cat: A microstimulation study. J. Neurophysiol. 2005, 94, 657-672. [CrossRef]

41. DiGiovanna, J.; Dominici, N.; Friedli, L.; Rigosa, J.; Duis, S.; Kreider, J.; Beauparlant, J.; van den Brand, R.; Schieppati, M.; Micera, S.; et al. Engagement of the Rat Hindlimb Motor Cortex across Natural Locomotor Behaviors. J. Neurosci. 2016, 36, 10440-10455. [CrossRef] [PubMed]

42. Bonizzato, M.; Pidpruzhnykova, G.; DiGiovanna, J.; Shkorbatova, P.; Pavlova, N.; Micera, S.; Courtine, G. Brain-controlled modulation of spinal circuits improves recovery from spinal cord injury. Nat. Commun. 2018, 9, 3015. [CrossRef] [PubMed]

43. Hollis, E.R., 2nd; Ishiko, N.; Yu, T.; Lu, C.C.; Haimovich, A.; Tolentino, K.; Richman, A.; Tury, A.; Wang, S.H.; Pessian, M.; et al. Ryk controls remapping of motor cortex during functional recovery after spinal cord injury. Nat. Neurosci. 2016, 19, 697-705. [CrossRef] [PubMed]

44. Lindner, R.; Puttagunta, R.; Di Giovanni, S. Epigenetic regulation of axon outgrowth and regeneration in CNS injury: The first steps forward. Neurotherapeutics 2013, 10, 771-781. [CrossRef]

45. Sun, H.; Miao, Z.; Wang, H.; Tao, Y.; Yang, J.; Cai, J.; Wang, J.; Wang, Y. DNA hydroxymethylation mediated traumatic spinal injury by influencing cell death-related gene expression. J. Cell. Biochem. 2018, 119, 9295-9302. [CrossRef]

46. Chhaya, S.J.; Quiros-Molina, D.; Tamashiro-Orrego, A.D.; Houle, J.D.; Detloff, M.R. Exercise-Induced Changes to the Macrophage Response in the Dorsal Root Ganglia Prevent Neuropathic Pain after Spinal Cord Injury. J. Neurotrauma 2019, 36, 877-890. [CrossRef]

47. Goldshmit, Y.; Lythgo, N.; Galea, M.P.; Turnley, A.M. Treadmill training after spinal cord hemisection in mice promotes axonal sprouting and synapse formation and improves motor recovery. J. Neurotrauma 2008, 25, 449-465. [CrossRef]

48. Field-Fote, E.C.; Roach, K.E. Influence of a locomotor training approach on walking speed and distance in people with chronic spinal cord injury: A randomized clinical trial. Phys. Ther. 2011, 91, 48-60. [CrossRef]

49. Li, X.; Wang, Q.; Ding, J.; Wang, S.; Dong, C.; Wu, Q. Exercise training modulates glutamic acid decarboxylase-65/67 expression through TrkB signaling to ameliorate neuropathic pain in rats with spinal cord injury. Mol. Pain 2020, 16, 1744806920924511. [CrossRef]

50. Rank, M.M.; Flynn, J.R.; Battistuzzo, C.R.; Galea, M.P.; Callister, R.; Callister, R.J. Functional changes in deep dorsal horn interneurons following spinal cord injury are enhanced with different durations of exercise training. J. Physiol. 2015, 593, 331-345. [CrossRef]

51. Tognini, P.; Napoli, D.; Pizzorusso, T. Dynamic DNA methylation in the brain: A new epigenetic mark for experience-dependent plasticity. Front. Cell Neurosci. 2015, 9, 331. [CrossRef] [PubMed]

52. Munoz, P.; Estay, C.; Diaz, P.; Elgueta, C.; Ardiles, A.O.; Lizana, P.A. Inhibition of DNA Methylation Impairs Synaptic Plasticity during an Early Time Window in Rats. Neural Plast. 2016, 2016, 4783836. [CrossRef] [PubMed]

53. Perrin, F.E.; Noristani, H.N. Serotonergic mechanisms in spinal cord injury. Exp. Neurol. 2019, 318, 174-191. [CrossRef] [PubMed]

54. Lang, B.T.; Cregg, J.M.; DePaul, M.A.; Tran, A.P.; Xu, K.; Dyck, S.M.; Madalena, K.M.; Brown, B.P.; Weng, Y.L.; Li, S.; et al Modulation of the proteoglycan receptor PTPsigma promotes recovery after spinal cord injury. Nature 2015, 518, 404-408. [CrossRef] [PubMed]

55. Kim, D.; Zai, L.; Liang, P.; Schaffling, C.; Ahlborn, D.; Benowitz, L.I. Inosine enhances axon sprouting and motor recovery after spinal cord injury. PLoS ONE 2013, 8, e81948. [CrossRef] [PubMed]

56. Agrawal, M.; Joshi, M. Urodynamic patterns after traumatic spinal cord injury. J. Spinal Cord Med. 2015, 38, 128-133. [CrossRef]

57. Hubscher, C.H.; Montgomery, L.R.; Fell, J.D.; Armstrong, J.E.; Poudyal, P.; Herrity, A.N.; Harkema, S.J. Effects of exercise training on urinary tract function after spinal cord injury. Am. J. Physiol. Renal Physiol. 2016, 310, F1258-F1268. [CrossRef]

58. Zlatev, D.V.; Shem, K.; Elliott, C.S. How many spinal cord injury patients can catheterize their own bladder? The epidemiology of upper extremity function as it affects bladder management. Spinal Cord 2016, 54, 287-291. [CrossRef]

59. Shin, H.Y.; Kim, H.; Kwon, M.J.; Hwang, D.H.; Lee, K.; Kim, B.G. Molecular and cellular changes in the lumbar spinal cord following thoracic injury: Regulation by treadmill locomotor training. PLoS ONE 2014, 9, e88215. [CrossRef]

60. Wang, C.; Wang, Q.; Lou, Y.; Xu, J.; Feng, Z.; Chen, Y.; Tang, Q.; Zheng, G.; Zhang, Z.; Wu, Y.; et al. Salidroside attenuates neuroinflammation and improves functional recovery after spinal cord injury through microglia polarization regulation. J. Cell. Mol. Med. 2018, 22, 1148-1166. [CrossRef]

61. Jung, S.Y.; Kim, D.Y.; Yune, T.Y.; Shin, D.H.; Baek, S.B.; Kim, C.J. Treadmill exercise reduces spinal cord injury-induced apoptosis by activating the PI3K/Akt pathway in rats. Exp. Ther. Med. 2014, 7, 587-593. [CrossRef] [PubMed]

62. Liu, Y.; Wang, X.; Li, W.; Zhang, Q.; Li, Y.; Zhang, Z.; Zhu, J.; Chen, B.; Williams, P.R.; Zhang, Y.; et al. A Sensitized IGF1 Treatment Restores Corticospinal Axon-Dependent Functions. Neuron 2017, 95, 817-833. [CrossRef] [PubMed] 
63. Huang, X.; Wang, C.; Zhou, X.; Wang, J.; Xia, K.; Yang, B.; Gong, Z.; Ying, L.; Yu, C.; Shi, K.; et al. Overexpression of the transcription factors OCT4 and KLF4 improves motor function after spinal cord injury. CNS Neurosci. 2020, 26, 940-951. [CrossRef] [PubMed]

64. Moore, D.L.; Blackmore, M.G.; Hu, Y.; Kaestner, K.H.; Bixby, J.L.; Lemmon, V.P.; Goldberg, J.L. KLF family members regulate intrinsic axon regeneration ability. Science 2009, 326, 298-301. [CrossRef] [PubMed]

65. Liu, J.; Zhang, C.; Liu, Z.; Zhang, J.; Xiang, Z.; Sun, T. Honokiol downregulates Kruppel-like factor 4 expression, attenuates inflammation, and reduces histopathology after spinal cord injury in rats. Spine 2015, 40, 363-368. [CrossRef] [PubMed]

66. Xu, J.H.; Qin, X.Z.; Zhang, H.N.; Ma, Y.X.; Qi, S.B.; Zhang, H.C.; Ma, J.J.; Fu, X.Y.; Xie, J.L.; Saijilafu, S. Deletion of Kruppel-like factor-4 promotes axonal regeneration in mammals. Neural Regen Res.. [CrossRef] 